\title{
Effects of permeable barriers on total ecosystem carbon stocks of mangrove forests and abandoned ponds in Demak District, Central Java, Indonesia
}

\author{
TRIALAKSITA SARI PRISKA ARDHANI ${ }^{1, \bullet}$, DANIEL MURDIYARSO ${ }^{2,3}$, CECEP KUSMANA $^{4}$ \\ ${ }^{1}$ Program of Applied Climatology, Faculty of Mathematics and Natural Sciences, Institut Pertanian Bogor. Jl. Meranti, IPB University Campus Dramaga, \\ Bogor 16680, West Java, Indonesia. Tel. +62-812-81694353, `email: ardhani_tsp@apps.ipb.ac.id. \\ ${ }^{2}$ Department of Geophysics and Meteorology, Faculty of Mathematics and Natural Sciences, Institut Pertanian Bogor. Jl. Meranti, IPB University \\ Campus Dramaga, Bogor 16680, West Java, Indonesia \\ ${ }^{3}$ Center for International Forestry Research. Jl. CIFOR, Situ Gede, Sindang Barang, Bogor 16115, West Java, Indonesia. \\ ${ }^{4}$ Department of Silviculture, Faculty of Forestry, Institut Pertanian Bogor. Jl. Ulin, IPB University Campus Dramaga, Bogor 16680, West Java, Indonesia
}

Manuscript received: 8 September 2020. Revision accepted: 20 October 2020.

\begin{abstract}
Authors. 2020. Effects of permeable barriers on total ecosystem carbon stocks of mangrove forests and abandoned ponds in Demak District, Central Java, Indonesia. Biodiversitas 21: 5298-5307. In this study, we observed the effects of constructing permeable barriers in the low-lying coastal zone and severely eroded coast of Demak District, Central Java, Indonesia, in the context of mangrove forest structures and carbon (C) dynamics. Forest structures were characterized by stand density, basal area, and ecological indices. The dynamics of C, expressed as total ecosystem carbon stocks (TECS), were compared in mangrove forests, abandoned ponds, and productive ponds by estimating $\mathrm{C}$ pools from above- and belowground biomass, dead organic matter, and soil. We found that permeable barriers, whether or not protect mangroves, resulted in the similarity of above- and belowground $\mathrm{C}$ due to no considerable difference in basal area. By contrast, soil properties in terms of bulk density, $\mathrm{C}$ concentration, $\mathrm{N}$ concentration, and C:N ratio statistically varied among sites. We discovered that changes in soil properties were associated with duration of permeable barriers, resulting in an increase of soil $\mathrm{C}$ in mangrove sites, i.e., $618.84 \pm 30.39 \mathrm{Mg} \mathrm{C} \mathrm{ha}^{-1}$; $704.13 \pm 17.73 \mathrm{Mg} \mathrm{C}^{-1}$; and 759.88 $\pm 15.26 \mathrm{Mg} \mathrm{C}^{-1}$ in 0-, 1-, and 4year-old permeable barriers, respectively. We highlight that these barriers were proved not only could enrich soil $\mathrm{C}$ in mangroves but also to provide a habitat for Avicennia sp. seedlings in the newly reclaimed coastline.
\end{abstract}

Keywords: Avicennia sp., ecological indices, forest structures, reclaimed coastline, soil properties

Abbreviations: AP4: abandoned ponds protected by four-year-old permeable barriers; PP0: productive ponds; MF0: mangrove forests without protection; MF1: mangrove forests protected by one-year-old permeable barriers; MF4: mangrove forests protected by fouryear-old permeable barriers

\section{INTRODUCTION}

Indonesia is home to $23 \%$ of the world's mangrove forests (Giri et al. 2010). A previous study reported that mangrove forests could store approximately 3-5 times more organic carbon $(\mathrm{C})$ than terrestrial forests in the tropics (Donato et al. 2011). Mangrove ecosystems currently face tremendous threats due to anthropogenic activities that release greenhouse gases, resulting in climate change and its severe impacts (e.g., sea-level rise). On average, total ecosystem carbon stocks (TECS) in Indonesian mangrove forests are estimated as approximately $1,083 \pm 378 \mathrm{Mg} \mathrm{C}$ $\mathrm{ha}^{-1}$ (Murdiyarso et al. 2015). However, researchers predict that under the business-as-usual scenario, more than 700,000 ha of mangrove forests in Indonesia will be converted into aquaculture ponds within the next two decades (Ilman et al. 2016). A case study conducted in Mahakam Delta revealed that the conversion of mangroves to shrimp ponds resulted in significant $\mathrm{C}$ losses that were equivalent to 226 years of soil $\mathrm{C}$ accumulation in natural mangrove forests (Arifanti et al. 2019). Furthermore, researchers predict that relative sea-level rise contributes to the reduction of mangrove area in the Pacific Islands, and there will be a $12 \%$ average annual reduction of mangrove area in the future (Gilman et al. 2006). To deal with these issues' impact, changes to the mangrove coastline in the Demak District, Central Java, Indonesia, were anticipated by constructing coastal barriers. In structures that could be considered to be a nature-based coastal defense and which have adopted the function of mangrove roots as sediment traps (Winterwerp et al. 2014), permeable barriers are protective structures on the coast made of wood and bamboo and are constructed on the edge of the mangrove facing the sea. Thus, permeable barriers can trap Ccontaining sediment through soil $\mathrm{C}$ accumulation and lead to changes in mangrove structures and soil physicochemical properties. Recent studies have shown that mangrove structures and soil physicochemical properties influence $\mathrm{C}$ storage in ecosystems (Kauffman et al. 2020; Sasmito et al. 2020). However, field data that could provide information on the effects of permeable barriers on TECS is currently still limited (Morris et al. 2019).

In this case study, by observing the effects of permeable barriers on the dynamics of TECS in three types of 
mangrove forests, abandoned ponds, and productive ponds in Demak District with the following objectives: (i) to assess the forest structure and ecological condition among mangrove forests; and (ii) to assess the effect of permeable barriers on soil properties and TECS in the observed environments, will provide valuable information for decision-makers about the effect of permeable barriers, which not only protect coasts from erosion but also provide C-containing sediment that can assist in climate change mitigation.

\section{MATERIALS AND METHODS}

\section{Study site}

This study was conducted from November 2018-August 2019 in the Demak District, on the north coast of Central Java, Indonesia (Figure 1). The climate in Demak District was characterized by a mean annual rainfall of 2,292 $\mathrm{mm}$ and a mean daily air temperature of $27.0^{\circ} \mathrm{C}$
(Climate-data.org 2019). Monsoonal weather affecting Demak District was the (wet) west monsoon that occurred from December to February, followed by the transitional season from March to May, and the (dry) east monsoon occurred from June to August, followed by the transitional season from September to November (Ervita and Marfai 2017)

The study was performed in two Sub-districts (i.e., Wedung Sub-district and Sayung Sub-district). Wulan Delta, located in Wedung Sub-district, has experienced sediment accretion in this delta's southwest direction, which was caused by the deposition of suspended materials from the Wulan River (Ervita and Marfai 2017). Berahan Kulon Village, one of the villages in the Wedung Subdistrict, experienced sedimentation in its coastal areas. In this region, we conducted the study in mangrove forests without protection (MF0), which has an area of 17.17 ha. Meanwhile, Sayung Sub-district topography was classified as a low-lying coastal zone with a slope of less than $2 \%$ and height of 0-5 $\mathrm{m}$ above sea level (Subardjo 2004).
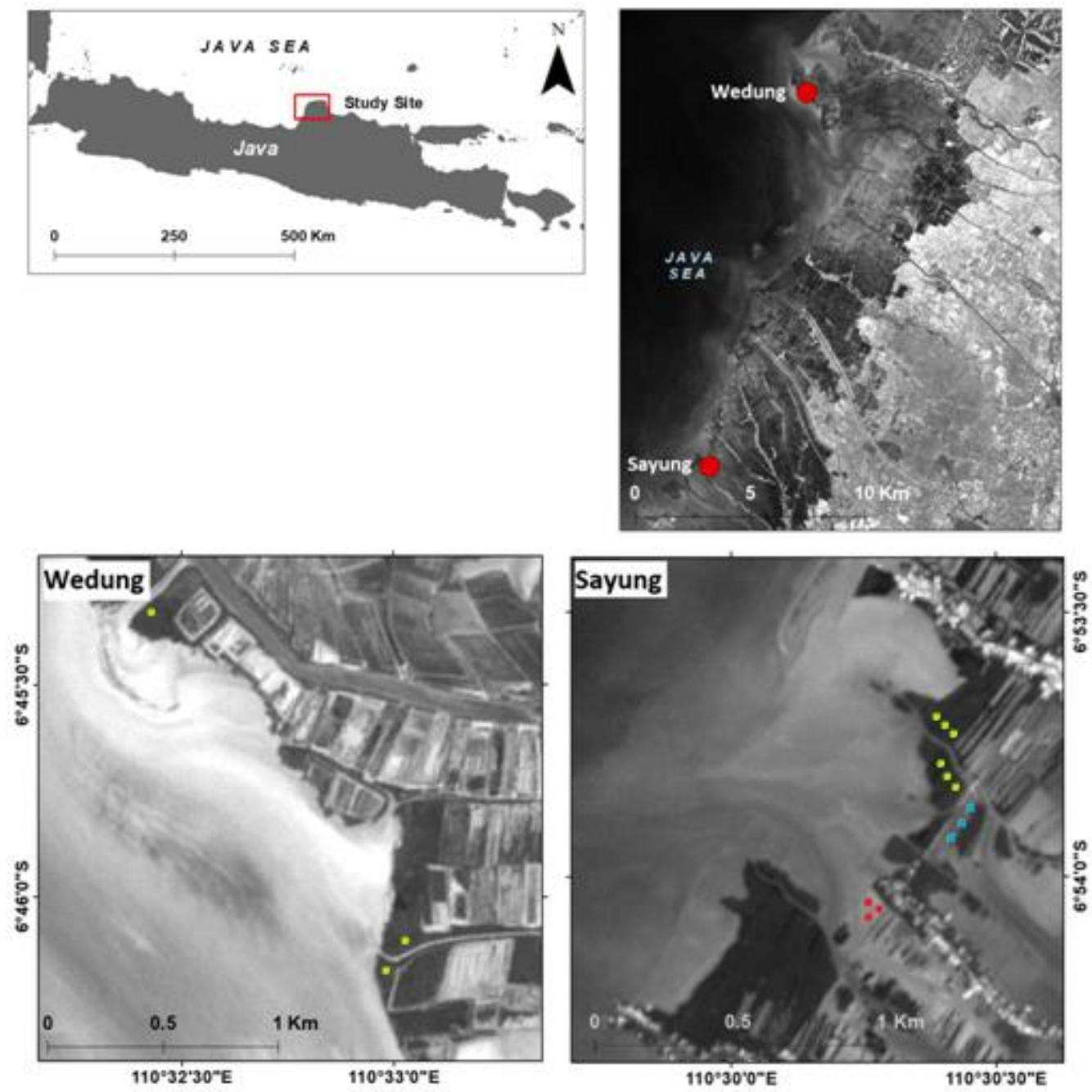

Figure 1. Study site in Wedung and Sayung Sub-districts, Demak District, Central Java, Indonesia. Green points demonstrate mangrove plots, red points express abandoned pond plots, and blue points symbolize productive pond plots (Source: Sentinel-2 earthexplorer.usgs.gov) 
A previous study reported that erosion rate of coastal areas in the Sayung Sub-district ranged between $4 \mathrm{~m}$ to 65 $\mathrm{m}$ year $^{-1}$ with an average of $25 \mathrm{~m}$ year $^{-1}$ (Muskananfola et al. 2020). Since this region suffered a massive conversion of mangrove forests to aquaculture ponds, this physical degradation reduced coastal areas (Marfai 2011). Moreover, the reduction of mangrove species composition and physical structures was an imperative impact demonstrated along this coastline (Thoai et al. 2019). In this region, the study observed 5.13 ha of mangrove forests protected by one-year-old permeable barriers (MF1), 2.63 ha of mangrove forests protected by four-year-old permeable barriers (MF4), 2.0 ha of abandoned ponds protected by four-year-old permeable barriers (AP4), and a 1.4 ha productive ponds (PP0)), located in Timbulsloko Village. Two sites of mangrove forests in the Sayung Subdistrict were the result of natural regeneration in abandoned ponds. A total of four mangrove species were recorded in Demak District in this present study, i.e., Avicennia alba, Avicennia marina, Rhizophora apiculata, and Rhizophora mucronata.

\section{Sampling design}

Stratified random sampling design was applied in this study to improve the inventory's precision and efficiency. Mangrove forest assessment followed the protocol outlined by Kauffman and Donato (2012). The first circular plot was established $15 \mathrm{~m}$ perpendicular to the riverine (Figure 2). Five additional linear plots were arranged to accommodate mangroves' inherent variation along the gradient, from the marine ecotone in the inland direction. Downed deadwood was measured using the line intercept technique that crossed the vertical sampling area (van Wagner 1968; Kauffman and Donato 2012).

\section{Assessment of forest structure}

Forest structure, which refers to the distribution of trees within a forest (e.g., species composition, tree density, and basal area), is crucial in mangrove conservation and management (Smith-III 1992). A common term to describe the number of tree stands per unit area is tree density, which is expressed as the number of trees per hectare, and basal area is expressed as the cross-sectional area of a tree at breast height, an attribute that is generally reported in square meters per hectare. The structure of mangrove forests was also assessed in terms of ecological indices to monitor different species' abundance. Calculation of Margalef richness index, Shannon-Wiener diversity index, and Pielou evenness index ratings were adapted from Jørgensen et al. (2005) and were modified by Hussain et al. (2012) to suit the range of ecological indices in wetland areas.

\section{Margalef richness index $(D)$}

Margalef index is a quantitative measurement of the number of different species in a given area (Margalef 1957). Based on the following formula, D expresses the Margalef richness index, $\mathrm{S}$ is the number of species, and $\mathrm{N}$ demonstrates the total number of individuals.

$$
\mathrm{D}=(\mathrm{S}-1) / \ln \mathrm{N}
$$

\section{Shannon-Wiener diversity index ( $\left.H^{\prime}\right)$}

The Shannon-Wiener index is commonly used to characterize species diversity within a community (Shannon 1963). Formula 2 involves several notations, i.e., $H^{\prime}$ is the Shannon-Wiener diversity index, $\mathrm{p}_{\mathrm{i}}$ denotes the proportion of individuals that belong to a particular species, $\mathrm{N}_{\mathrm{i}}$ is the number of individuals in a particular species, and $\mathrm{N}$ expresses the total number of individuals.

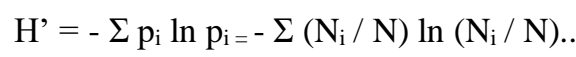

\section{Pielou evenness index ( $\left.J^{\prime}\right)$}

Pielou index expresses the evenness of species abundance in a community (Pielou 1966). In this calculation, J' symbolizes the Pielou evenness index, H' is the Shannon-Wiener diversity index, $\mathrm{H}_{\text {max }}$ demonstrates $^{\prime}$ the maximum possible value of Shannon diversity, and $S$ is the total number of species.

$$
\mathrm{J}^{\prime}=\mathrm{H}^{\prime} / \mathrm{H}^{\prime}{ }_{\max }=\mathrm{H}^{\prime} / \ln \mathrm{S}
$$

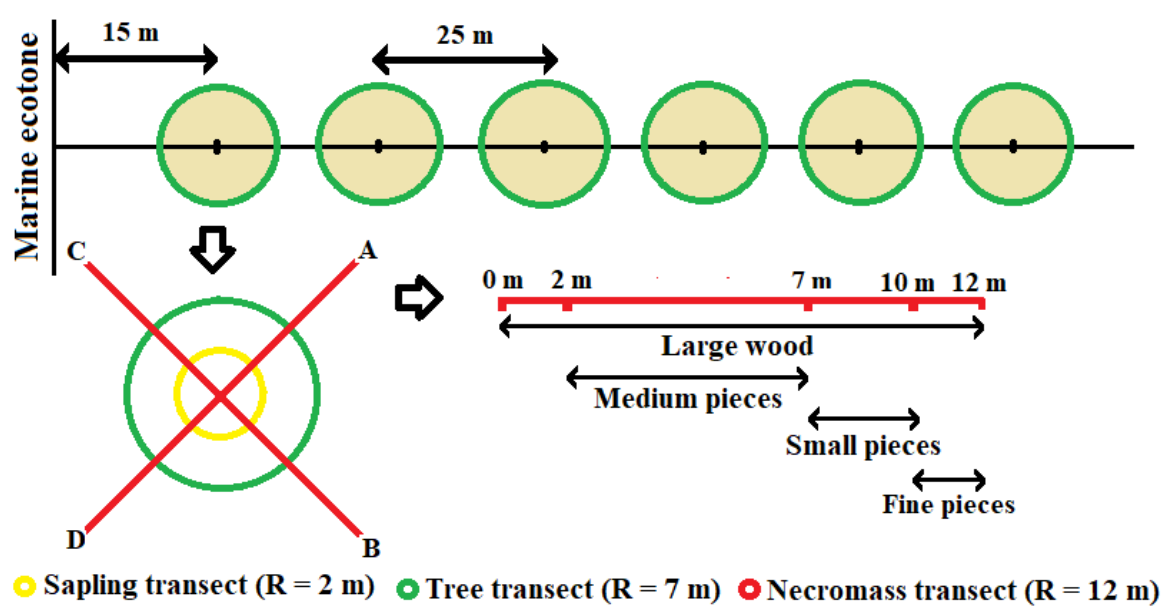

Figure 2. Plot layout of mangrove inventory in Demak District. R denotes radius (modified from Kauffman and Donato 2012) 


\section{Important Value Index (IVI)}

The IVI was used in this study to perform mangrove species' dominance and ecological success. The IVI represents the importance of species and essential functions within the community. This index was calculated as the sum of relative frequency, relative dominance, and relative density (Muller-Dubois and Ellenberg 1974; Citron and Novelli 1984).

\section{Bray-Curtis dissimilarity index}

The Bray-Curtis index is the most widely used dissimilarity coefficient for biological communities. This index was developed by Bray and Curtis (1958) to describe the degree of community dissimilarity between two sites. Since the Bray-Curtis dissimilarity index ranges from 0-1, assessing floristic similarity (1-B) can be quantified by calculating the dissimilarity and multiplying it with 100 to demonstrate the similarity percentage. Based on formula 4 , $\mathrm{B}$ denotes the Bray-Curtis index, and $\mathrm{p}_{i a l i b}$ is the IVI of species $i$ in plots $a$ and $b$, respectively.

$$
\mathrm{B}=\Sigma\left|\mathrm{p}_{i a}-\mathrm{p}_{i b}\right| / \Sigma\left(\mathrm{p}_{i a}+\mathrm{p}_{i b}\right)
$$

\section{Assessment of carbon stocks}

C stocks, which are contained in biomass and included live and standing dead trees, downed deadwood (or necromass), and soil, were observed and summed up to estimate the TECS of each plot. Only soil samples were collected in the abandoned pond and productive pond plots.

Aboveground carbon (AGC) and belowground carbon (BGC)

The primary data were recorded for $\mathrm{C}$ stock assessment comprised of species identification, main stem diameter, and decay status. Generally, tree diameters were measured above the main stem's stage roots, and the tree diameter at $137 \mathrm{~cm}$ above the ground, also known as diameter at breast height (DBH). For stilt-rooted species (e.g., Rhizophora spp.), tree diameter was measured above the highest stilt root (Pearson et al. 2005). The trees defined by DBH had a diameter greater than $5 \mathrm{~cm}$ and were measured within the 7 $\mathrm{m}$ radius circular subplot. Saplings, which had smaller than $5 \mathrm{~cm}$ in diameter, were measured in the $2 \mathrm{~m}$ radius circular subplot (Kauffman and Donato 2012). In this study, tree and root biomass were calculated using the allometric equations summarized in Table 1. Estimation of decayed standing dead trees followed the remaining biomass concentration of a decaying class of 1 (97.5\%), $2(80 \%)$, and $3(50 \%)$ (Kauffman and Donatto 2012). C conversion factors of aboveground trees and belowground roots were 0.47 and 0.39, respectively (Kauffman and Donato 2012). Formula 5 was used to assess AGC and BGC per unit area.

Vegetation $\mathrm{C}=$ biomass $\times \mathrm{C}$ conversion factor

\section{Downed deadwood C}

Downed deadwood or necromass is one of the variables used to assess ecosystem $\mathrm{C}$ sinks and the effects of natural and human disturbances. According to each size class, downed deadwood was assessed by collecting fallen stem and branch debris on the forest floor (fine, small, medium, and large). The study calculated $\mathrm{C}$ stocks of this pool with the $\mathrm{C}$ conversion factor of 0.50 (Kauffman and Donato 2012). Equation 6 was applied to estimate the necromass $C$ in this present study:

Necromass $\mathrm{C}=$ wood mass $\mathrm{x} \mathrm{C}$ conversion factor .... (6)

\section{Soil C}

Soil $\mathrm{C}$ was estimated by collecting soil samples using a $5.5 \mathrm{~cm}$ diameter stainless steel open-faced cylindrical soil auger at different depth intervals. In each subplot, soil samples were collected $5 \mathrm{~cm}$ in length or $59.42 \mathrm{~cm}^{3}$ in volume in each depth interval of 0-15, 15-30, 30-50, 50100, and 100-300 cm (Kauffman and Donato 2012). Therefore, this study collected five soil samples in each core. Soil properties were observed in all sampling sites, including bulk density, $\mathrm{C}$ concentration, nitrogen $(\mathrm{N})$ concentration, and $\mathrm{C}: \mathrm{N}$ ratio. Soil $\mathrm{C}$ and $\mathrm{N}$ concentrations were analyzed using a dry combustion technique (LECO CNS elemental analyzer) in the Indonesian Agency for Agricultural Research and Development (IAARD), Bogor. The following equation was used to estimate soil C:

Soil $\mathrm{C}=$ bulk density $\mathrm{x}$ depth $\mathrm{x} \mathrm{C}$ concentration (7)

Table 1. Allometric equation of tree and root used in this study for estimating vegetation biomass

\begin{tabular}{|c|c|c|}
\hline Species name & Allometric equation & Reference \\
\hline \multicolumn{3}{|c|}{ Above-ground biomass ( $W_{\text {top }}$ in $\mathrm{kg}$ ) } \\
\hline Rhizophora apiculata & $\mathrm{W}_{\mathrm{top}}=0.235 \mathrm{DBH}^{2.42}$ & Ong et al. (2004) \\
\hline Avicennia marina, & $\mathrm{W}_{\mathrm{top}}=0.251 \rho \mathrm{D}^{2.46 *}$ & Komiyama et al. (2005) \\
\hline Avicennia alba, & where $\rho$ as wood density was determined from ICRAF database & \\
\hline Rhizophora mucronata & (db.worldagroforestry.org/wd) & \\
\hline \multicolumn{3}{|c|}{ Below-ground biomass ( $\mathrm{W}_{\text {root }}$ in $\mathrm{kg}$ ) } \\
\hline Rhizophora apiculata & $\mathrm{W}_{\mathrm{R}}=0.00698 \mathrm{DBH}^{2.61}$ & Ong et al. (2004) \\
\hline Avicennia marina, & $\mathrm{W}_{\mathrm{R}}=0.199 \rho^{0.899} \mathrm{D}^{2.22 *}$ & Komiyama et al. (2005) \\
\hline Avicennia alba, & where $\rho$ as wood density was determined from ICRAF database & \\
\hline Rhizophora mucronata & (db.worldagroforestry.org/wd) & \\
\hline
\end{tabular}




\section{Statistical analysis}

Differences in vegetation structures among mangrove forests and soil physicochemical properties across sampling sites were tested using the analysis of variance (ANOVA). When the ANOVA result was significant, this study applied a post hoc Tukey's honest significant difference (HSD) test to assess mean values' significance. KruskalWallis, a non-parametric significance test, was applied when the data were not normal and not homogenously distributed. The similarity of species composition between two mangrove forests was applied to square-root transform data, and the data were quantified using PRIMER v5 (Clarke and Gorley 2006). Data given in the text were mean \pm standard error. A 95\% confidence interval was applied in all statistical tests. A confidence interval is a crucial definition of scientific uncertainty.

\section{RESULTS AND DISCUSSION}

\section{Effect of permeable barriers on vegetation structures} and ecological conditions of mangrove forests

Mangrove density is an essential component in assessing coastal forests' protection functions and its ability to recover from environmental disturbances. In Demak District, tree density ranged from $1378 \pm 128$ to $2244 \pm 237$ individuals ha ${ }^{-1}$ (Table 2). Statistically, this study revealed a considerable variation in tree density in MF0, MF1, and MF4 ( $p<0.05)$. By contrast, mangroves' stand basal area, ranging from $9.29 \pm 1.33$ to $13.56 \pm 1.72 \mathrm{~m}^{2} \mathrm{ha}^{-1}$, did not differ significantly in Demak District $(p>0.05)$.

Margalef index (D), Shannon-Wiener index (H'), Pielou index (J'), Important value index (IVI), and similarity of species composition across mangrove forests in this case study are demonstrated in Table 3. Generally, it is known that the ecological conditions of mangrove forests in Demak District were categorized as disturbed habitats (D $=0.59)$ with bad species diversity $\left(H^{\prime}=0.87\right)$. However, this study found that MF4 had a semi-balanced species evenness level $\left(J^{\prime}=0.71\right)$, while other mangrove forests had a balanced level of species distribution $(\mathrm{J}=0.83)$. MF4 had the highest index of species richness and diversity $(\mathrm{D}=$ $0.56 ; \mathrm{H}^{\prime}=0.98$, respectively), but this site was dominated by Avicennia marina (IVI $=146.29$ ). Among the living trees and saplings, Avicennia marina had the highest IVI in all mangrove areas, i.e., 155.44 and 205.86, respectively. This study also reported that more than $75 \%$ of species composition was homogenous in all mangrove forests.

\section{Effect of permeable barriers on soil properties and total ecosystem carbon stocks}

Soil properties influencing soil $\mathrm{C}$ determination are shown in Table 4, with a statistical value of $p<0.05$ across sampling plots. Our results showed that mangrove forests in Wedung Sub-district $\left(\mathrm{MF} 0=0.95 \pm 0.04 \mathrm{~g} \mathrm{~cm}^{-3}\right.$ ) had a significantly lower value of soil bulk density than in Sayung Sub-district $\left(1.47 \pm 0.04 \mathrm{~g} \mathrm{~cm}^{-3}\right.$ in MF1 and $1.62 \pm$ $0.06 \mathrm{~g} \mathrm{~cm}^{-3}$ in MF4) $(p<0.05)$. Besides, the study discovered that soil bulk density was significantly different between two groups, i.e., MF1, MF4, and PP0 $(1.61 \pm 0.02$ $\left.\mathrm{g} \mathrm{cm}^{-3}\right)$; MF1 and AP4 $\left(1.33 \pm 0.02 \mathrm{~g} \mathrm{~cm}^{-3}\right)(p<0.05$; Tukey HSD).

Table 3. Margalef richness index, Shannon-Wiener diversity index, Pielou evenness index, Important value index, and similarity of mangrove species composition in Demak District, Central Java, Indonesia

\begin{tabular}{|c|c|c|c|c|}
\hline \multirow{2}{*}{ Parameters } & \multicolumn{3}{|c|}{ Sites } & \multirow{2}{*}{ Average } \\
\hline & MF0 & MF1 & MF4 & \\
\hline Richness index (D) & 0.20 & 0.41 & 0.56 & 0.59 \\
\hline Diversity index (H') & 0.58 & 0.91 & 0.98 & 0.87 \\
\hline Evenness index (J') & 0.83 & 0.83 & 0.71 & $0.63 *$ \\
\hline \multicolumn{5}{|l|}{ Important value index (IVI) } \\
\hline \multicolumn{5}{|l|}{ Tree } \\
\hline Avicennia alba & 106.85 & 94.30 & 94.34 & 89.66 \\
\hline Avicennia marina & 193.15 & 154.98 & 146.29 & 155.44 \\
\hline Rhizophora apiculata & - & - & 13.77 & 11.06 \\
\hline Rhizophora mucronata & - & 50.72 & 45.60 & 43.84 \\
\hline \multicolumn{5}{|l|}{ Sapling } \\
\hline Avicennia alba & 37.20 & 82.85 & 78.36 & 62.18 \\
\hline Avicennia marina & 262.80 & 164.00 & 221.64 & 205.86 \\
\hline Rhizophora mucronata & - & 53.15 & - & 31.96 \\
\hline \multicolumn{5}{|l|}{$\begin{array}{l}\text { Similarity of species } \\
\text { composition between } \\
\text { mangrove forests }(\%)\end{array}$} \\
\hline MF0 & 100 & 82.82 & 77.19 & - \\
\hline MF1 & 82.82 & 100 & 92.79 & - \\
\hline MF4 & 77.19 & 92.79 & 100 & - \\
\hline
\end{tabular}

Note: *: involving all mangrove species found in Demak District.

Table 2. Characteristics of mangrove forest structures in Demak District, Central Java, Indonesia

\begin{tabular}{lllllll}
\hline Sampling site & $\begin{array}{l}\text { Age of } \\
\text { permeable barriers } \\
\text { (year) }\end{array}$ & $\begin{array}{l}\text { Forest structure } \\
\text { Tree density } \\
\left(\text { ind ha }^{-1}\right)\end{array}$ & $\begin{array}{l}\text { Basal area } \\
\left(\mathbf{m}^{\mathbf{2}} \mathbf{~ h a}^{-\mathbf{1}}\right)\end{array}$ & Richness & Diversity & Evenness \\
\hline & & $1772 \pm 104$ & $12.43 \pm 1.07$ & Disturbed & Bad & Balanced \\
MF0 & - & $1378 \pm 128$ & $9.29 \pm 1.33$ & Disturbed & Bad & $\begin{array}{l}\text { Balanced } \\
\text { MF1 }\end{array}$ \\
One & $2244 \pm 237$ & $13.56 \pm 1.72$ & Disturbed & Bad & Semi-balanced
\end{tabular}

Note: * based on rating ranges of ecological indices outlined in Jorgensen et al. (2005) and Hussain et al. (2012) 
Table 4. Soil physicochemical properties in Wedung and Sayung plots in Demak District, Central Java, Indonesia

\begin{tabular}{|c|c|c|c|c|c|c|c|}
\hline Location/Plot & Sub-plot & $\begin{array}{l}\text { Salinity } \\
\text { (ppt) }\end{array}$ & $\begin{array}{l}\text { Soil depth } \\
\text { (cm) }\end{array}$ & $\begin{array}{l}\text { Bulk density } \\
\left(\mathrm{g} \mathrm{cm}^{-3}\right)\end{array}$ & $\% \mathrm{C}$ & $\% \mathbf{N}$ & $\mathrm{C}: \mathrm{N}$ ratio \\
\hline \multirow{3}{*}{ Wedung/MF0 } & MF0-1 & 41.95 & 300 & 1.03 & 2.15 & 0.80 & 2.69 \\
\hline & MF0-2 & 38.82 & 300 & 0.89 & 2.25 & 0.78 & 2.89 \\
\hline & MF0-3 & 36.55 & 300 & 0.91 & 2.17 & 0.79 & 2.77 \\
\hline Mean \pm SE & & 39.11 & & $0.95 \pm 0.04$ & $2.19 \pm 0.03$ & $0.79 \pm 0.01$ & $2.78 \pm 0.06$ \\
\hline \multirow[t]{3}{*}{ Sayung/MF1 } & MF1-1 & 32.00 & 200 & 1.41 & 2.26 & 0.68 & 3.36 \\
\hline & MF1-2 & 33.33 & 200 & 1.54 & 2.31 & 0.69 & 3.39 \\
\hline & MF1-3 & 32.00 & 300 & 1.46 & 2.18 & 0.69 & 3.23 \\
\hline Mean \pm SE & & 32.44 & & $1.47 \pm 0.04$ & $2.25 \pm 0.04$ & $0.69 \pm 0.00$ & $3.33 \pm 0.05$ \\
\hline \multirow{3}{*}{ Sayung/MF4 } & MF4-1 & 33.00 & 200 & 1.69 & 2.18 & 0.66 & 3.36 \\
\hline & MF4-2 & 29.33 & 200 & 1.67 & 2.13 & 0.65 & 3.37 \\
\hline & MF4-3 & 30.00 & 200 & 1.50 & 2.14 & 0.69 & 3.14 \\
\hline Mean $\pm \mathrm{SE}$ & & 30.78 & & $1.62 \pm 0.06$ & $2.15 \pm 0.01$ & $0.67 \pm 0.01$ & $3.29 \pm 0.07$ \\
\hline \multirow[t]{3}{*}{ Sayung/AP4 } & AP4-1 & 32.00 & 200 & 1.36 & 2.06 & 0.75 & 2.79 \\
\hline & AP4-2 & 30.30 & 200 & 1.30 & 2.05 & 0.85 & 2.40 \\
\hline & AP4-3 & 31.50 & 200 & 1.34 & 2.13 & 0.79 & 2.70 \\
\hline Mean $\pm \mathrm{SE}$ & & 31.27 & & $1.33 \pm 0.02$ & $2.08 \pm 0.03$ & $0.80 \pm 0.03$ & $2.63 \pm 0.12$ \\
\hline \multirow[t]{3}{*}{ Sayung/PP0 } & PP0-1 & 30.00 & 200 & 1.66 & 2.12 & 0.79 & 2.67 \\
\hline & PP0-2 & 30.30 & 200 & 1.61 & 2.16 & 0.84 & 2.59 \\
\hline & PP0-3 & 29.75 & 200 & 1.58 & 2.09 & 0.76 & 2.75 \\
\hline Mean \pm SE & & 30.02 & & $1.61 \pm 0.02$ & $2.12 \pm 0.02$ & $0.80 \pm 0.02$ & $2.67 \pm 0.05$ \\
\hline$p$-value* & & & & 0.00 & 0.13 & 0.05 & 0.00 \\
\hline$p$-value ${ }^{* *}$ & & & & 0.00 & 0.01 & 0.03 & 0.00 \\
\hline
\end{tabular}

Note: $*$ : in mangrove forests; $* *$ : in sampling sites

C concentration across mangrove forests in Demak District ranged from $2.15 \pm 0.01$ to $2.25 \pm 0.04$. There was no significant variation of $\mathrm{C}$ concentration in mangrove forests $(p>0.05)$. However, soil C concentration in MF1 was statistically higher than $\mathrm{C}$ concentration in AP4 $(2.08 \pm$ $0.03)$ and PP0 $(2.12 \pm 0.02)(p<0.05$; Tukey HSD). This study also reported that $\mathrm{N}$ concentration was significantly lower in MF1 $(0.69 \pm 0.00)$ and MF4 $(0.67 \pm 0.01)$ than other sampling sites, i.e., $0.79 \pm 0.01$ in MF0, $0.80 \pm 0.03$ in AP4, and $0.80 \pm 0.02$ in PP0 $(p<0.05$; Tukey HSD). Therefore, differences in $\mathrm{C}$ and $\mathrm{N}$ concentrations were implied in $\mathrm{C}: \mathrm{N}$ ratio. The $\mathrm{C}: \mathrm{N}$ ratio across mangrove forests ranged from $2.78 \pm 0.06$ to $3.33 \pm 0.05$, while in AP4 and PP0 was only $2.63 \pm 0.12$ and $2.67 \pm 0.05$, respectively. The C:N ratio was statistically different among mangrove forests and sampling sites, with the higher value found in MF1 and MF4 $(p<0.05$; Tukey HSD).

Table 5 summarizes the $\mathrm{C}$ stocks in all pools of the Wedung and Sayung sites. AGC and BGC are essential sinks of $\mathrm{C}$ to be deposited in mangrove forests' floor and soil. The AGC of mangroves in the Demak District ranged from $35.22 \pm 3.19 \mathrm{Mg} \mathrm{C}^{-1}$ to $53.76 \pm 3.46 \mathrm{Mg} \mathrm{C}^{-1}$, while BGC varied from $14.20 \pm 1.06 \mathrm{Mg} \mathrm{C}^{-1}$ to $22.93 \pm$ $2.14 \mathrm{Mg} \mathrm{C} \mathrm{ha}{ }^{-1}$. However, there was no considerable variation found in $\mathrm{AGC}$ and $\mathrm{BGC}$ across mangrove sites $(p$ $>0.05)$.

Deadwood C stocks in MF0, MF1, and MF4 were 10.02 $\pm 1.36 \mathrm{Mg} \mathrm{C} h a^{-1}, 5.74 \pm 1.46 \mathrm{Mg} \mathrm{C}^{-1}$, and $2.23 \pm 1.01$ $\mathrm{Mg} \mathrm{C} \mathrm{ha}^{-1}$, respectively. A significant difference in $\mathrm{C}$ stocks of necromass was observed between MF0 and MF4 $(p<0.05$; Tukey HSD). Besides, this study discovered a considerable variance in soil $\mathrm{C}$ pools across sampling sites $(p<0.05)$. Among mangrove sites, differences in soil physicochemical properties resulted in a range of soil $\mathrm{C}$, i.e., $618.84 \pm 30.39 \mathrm{Mg} \mathrm{C} \mathrm{ha}^{-1}$ in MF0, $704.13 \pm 17.73 \mathrm{Mg}$ $\mathrm{C} \mathrm{ha}{ }^{-1}$ in MF1, and $759.88 \pm 15.26 \mathrm{Mg} \mathrm{C} \mathrm{ha}^{-1}$ in MF4. Across the non-mangrove site, soil C in PP0 (735.57 \pm $20.61 \mathrm{Mg} \mathrm{C} \mathrm{ha}^{-1}$ ) was significantly higher than soil $\mathrm{C}$ in AP4 (610.82 $\left.\pm 29.31 \mathrm{Mg} \mathrm{Cha}^{-1}\right)(p<0.05$; Tukey HSD).

The average values of TECS significantly ranged from $705.55 \pm 30.62 \mathrm{Mg} \mathrm{C}^{-1}$ to $826.14 \pm 24.41 \mathrm{Mg} \mathrm{C} \mathrm{ha}^{-1}$ ( $p$ $<0.05$; Figure 3). Since this study did not find any significant difference in AGC and BGC among mangrove forests in Wedung and Sayung Sub-districts, the main contribution of the TECS variation was derived from soil C. Likewise, TECS in the non-mangrove site, which only originated from C pools in soil, stored $610.82 \pm 29.31 \mathrm{Mg}$ $\mathrm{C} \mathrm{ha}^{-1}$ and $735.57 \pm 20.61 \mathrm{Mg} \mathrm{C}^{-1}$ in AP4 and PP0, respectively $(p<0.05$; Tukey HSD). 
Table 5. Values of C pools used to estimate total ecosystem carbon stocks in Wedung and Sayung plots in Demak District, Central Java, Indonesia

\begin{tabular}{|c|c|c|c|c|c|c|}
\hline Location/plot & Sub-plot & $\begin{array}{l}\text { Aboveground C } \\
\left(\mathrm{Mg} \mathrm{C} \mathrm{ha-1)}^{-1}\right)\end{array}$ & $\begin{array}{l}\text { Belowground C } \\
\left(\mathrm{Mg} \mathrm{C} \mathrm{ha}^{-1}\right)\end{array}$ & $\begin{array}{c}\text { Deadwood C } \\
\left(\mathrm{Mg} \mathrm{C} \mathrm{ha}^{-1}\right)\end{array}$ & $\begin{array}{l}\text { Soil C } \\
\left(\mathrm{Mg} \mathrm{C} \mathrm{ha}^{-1}\right)\end{array}$ & $\begin{array}{l}\text { TECS } \\
\left(\mathrm{Mg} \mathrm{C} \mathrm{ha}^{-1}\right)\end{array}$ \\
\hline \multirow[t]{3}{*}{ Wedung/MF0 } & MF0-1 & 50.11 & 20.26 & 7.53 & 662.15 & 740.06 \\
\hline & MF0-2 & 60.49 & 27.17 & 10.34 & 634.12 & 732.12 \\
\hline & MF0-3 & 50.67 & 21.35 & 12.21 & 560.25 & 643.94 \\
\hline Mean $\pm \mathrm{SE}$ & & $53.76 \pm 3.46$ & $22.93 \pm 2.14$ & $10.02 \pm 1.36$ & $618.84 \pm 30.39$ & $705.55 \pm 30.62$ \\
\hline \multirow[t]{3}{*}{ Sayung/MF1 } & MF1-1 & 32.99 & 13.62 & 5.40 & 670.60 & 722.62 \\
\hline & MF1-2 & 41.52 & 16.25 & 3.39 & 730.90 & 792.06 \\
\hline & MF1-3 & 31.16 & 12.73 & 8.43 & 710.89 & 763.21 \\
\hline Mean \pm SE & & $35.22 \pm 3.19$ & $14.20 \pm 1.06$ & $5.74 \pm 1.46$ & $704.13 \pm 17.73$ & $759.30 \pm 20.14$ \\
\hline \multirow[t]{3}{*}{ Sayung/MF4 } & MF4-1 & 53.56 & 20.60 & 4.08 & 789.06 & 867.29 \\
\hline & MF4-2 & 53.49 & 22.28 & 2.01 & 750.56 & 828.34 \\
\hline & MF4-3 & 30.92 & 12.83 & 0.60 & 738.45 & 782.80 \\
\hline Mean \pm SE & & $45.99 \pm 7.53$ & $18.57 \pm 2.91$ & $2.23 \pm 1.01$ & $759.88 \pm 15.26$ & $826.14 \pm 24.41$ \\
\hline \multirow[t]{3}{*}{ Sayung/AP4 } & AP4-1 & - & - & - & 628.64 & 628.64 \\
\hline & AP4-2 & - & - & - & 553.54 & 553.54 \\
\hline & AP4-3 & - & - & - & 650.28 & 650.28 \\
\hline Mean \pm SE & & - & - & - & $610.82 \pm 29.31$ & $610.82 \pm 29.31$ \\
\hline \multirow[t]{3}{*}{ Sayung/PP0 } & PP0-1 & - & - & - & 728.11 & 728.11 \\
\hline & PP0-2 & - & - & - & 704.19 & 704.19 \\
\hline & PP0-3 & - & - & - & 774.40 & 774.40 \\
\hline Mean \pm SE & & - & - & - & $735.57 \pm 20.61$ & $735.57 \pm 20.61$ \\
\hline$p$-value* & & 0.25 & 0.08 & 0.02 & 0.01 & 0.04 \\
\hline$p$-value $* *$ & & - & - & - & 0.00 & 0.00 \\
\hline
\end{tabular}

Note: *: among mangrove forests; **: among sampling sites

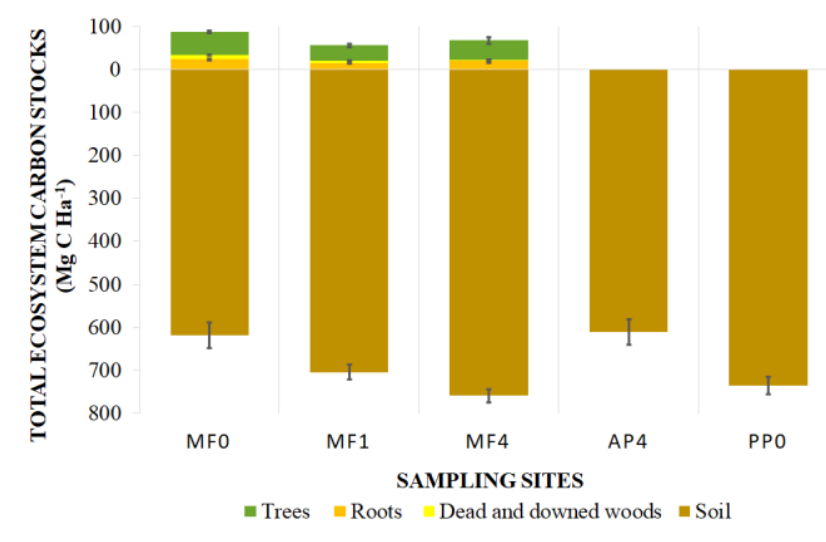

Figure 3. Total ecosystem carbon stocks in MF0 (mangrove forests without protection), MF1 (mangrove forests protected by one-year-old permeable barriers), MF4 (mangrove forests protected by four-year-old permeable barriers), AP4 (abandoned ponds protected by four-year-old permeable barriers), and PP0 (productive ponds)

\section{Discussion}

Effectiveness of permeable barriers for capturing carbon in mangrove forests

Permeable barriers constructed in Sayung Sub-district are used to restore the sediment balance in certain areas.
They effectively protect the coastline from erosion and stimulate sedimentation in coastal areas, as seen in Vietnam and Thailand (Saengsupavanich 2013; Schmittet al. 2013). Factors that enhance the effectiveness of these structures are: (i) the permeable barriers were spatially arranged to align with the water flow and sediment transport (Smits 2016), (ii) the permeable barriers allowed the waves to dissipate similarly to wave attenuation due to mangrove roots (Smits 2016), and (iii) the permeable barriers prevented the mobilization of the soil layer as well as accelerated consolidation of the mud layer (Borsje et al. 2019). Since these three factors, these barriers gradually changed soil properties in mangrove forests. However, findings showed that $\mathrm{C}$ concentration was not significantly varied across mangrove forests, whether or not mangroves are protected by structural barriers, suggesting that the mangrove forests were similar in age (Sahu et al. 2019). By contrast, the lower $\mathrm{N}$ concentration in two mangrove forests located in Sayung Sub-district implied that mangrove areas in this region allowed mangroves to grow better because $\mathrm{N}$ was the nutrient potentially suppressing the growth of mangrove (Lovelock et al. 2004). Consequently, a higher $\mathrm{C}: \mathrm{N}$ ratio in $\mathrm{MF} 1$ and $\mathrm{MF} 4$ suggested high above- and belowground vegetation input which leaves residues in the soil, low carbonate content, and low humification (Sabiene et al. 2010). A previous 
study also reported that the $\mathrm{C}: \mathrm{N}$ ratio could identify terrestrial organic matter because they had a higher relative $\mathrm{N}$ content than in the aquatic organic matter (Tyson 1995). Therefore, a low value of $\mathrm{C} / \mathrm{N}$ ratio in mangrove forests indicated that marine or estuarine particulate suspended matter was deposited in mangrove sediments (Bouillon et al. 2003). These findings were consistent with this case study's conditions. Since the estuary in Wedung Subdistrict is located more than $14 \mathrm{~km}$ from Sayung Subdistrict, they did not have any connection with each other. Coastal area in Wedung Sub-district received suspended materials from Wulan River, which led to sediment accretion in Wulan Delta.

Changes in soil characteristics may subsequently affect the ability of mangrove forests in storing C. Mangrove forests with or without the protection of permeable barriers varied in tree density, but these forests were not significantly different in terms of basal area, implying that AGC and BGC did not generously contribute to the variation of TECS. Simultaneously, since the low value of $\mathrm{C}$ stock in the form of necromass was found, this result suggested that a large amount of soil $\mathrm{C}$ in mangrove forests should be more responsible for the variation of TECS. By comparing mangrove forests without barriers and mangroves with different barrier ages, this study discovered that the duration of permeable barriers in coastal areas affected the deposited soil $\mathrm{C}$ caused by past activities. MF0 (618.84 $\left.\pm 30.39 \mathrm{Mg} \mathrm{C} \mathrm{ha}^{-1}\right)$ and MF1 $\left(704.13 \pm 17.73 \mathrm{Mg} \mathrm{C} \mathrm{ha}^{-1}\right)$ had a lower value of soil $\mathrm{C}$ than MF4 (759.88 $\left.\pm 15.26 \mathrm{Mg} \mathrm{C} \mathrm{ha}^{-1}\right)$, which implied that a longer duration of permeable barriers in MF4 was able to store more C-containing sediment than in the other sites. Nevetheless, this study realized that permeable barriers used bio-degradable materials in the construction. Wood and bamboo are two primary materials that can decompose become organic matter and deposit into the mangrove forests. However, the amount of organic matter in these materials was considered to be a minor and negligible contribution to the soil $\mathrm{C}$ variation in this present study. By comparing our findings to naturally regenerated mangrove forests in Vietnam, the mean value of TECS in Demak District (763.66 $\pm 21.58 \mathrm{Mg} \mathrm{C} \mathrm{ha}^{-1}$ ) is slightly lower than TECS in Kien Vang Protection Forest, which has TECS on average of $844 \pm 58 \mathrm{Mg} \mathrm{C} \mathrm{ha}^{-1}$ (Nam et al. 2016). However, mangrove forests in this case study have TECS about two times higher than restored mangroves in Hau Loc Forest (310.3 $\left.\pm 21.3 \mathrm{Mg} \mathrm{C} \mathrm{ha}^{-1}\right)$ (Pham et al. 2017).

\section{Effectiveness of permeable barriers for mangrove species colonization}

Soil properties of mangrove forests in the context of bulk density were found lower in Wedung Sub-district than Sayung Sub-district. This variation is due to the differences in root biomass activities, which promote biological processes that result in macropores' creation. Therefore, this process lead to an increase in water permeability and reduction in compaction, which affect the supply of rootzone air and available nutrients from mangrove soil for plant tissues. This assessment also discovered that the similarity in the high value of soil bulk density in mangrove forests was occurred in Sayung Sub-district (MF1 and MF4) and aquaculture ponds (PP0), implying that these three sites experienced similar pond construction treatments in the past, which led to soil compaction. During the pond constructions, these areas experienced a reduction in air volume, which was generally followed by changes in soil structure, pore size distribution, and soil strength. Particularly in MF1 and MF4, the high mean of soil bulk densities was caused by these areas experienced not only soil compaction due to aquaculture pond construction in the past but also soil consolidation, a reduction in the water volume, which was caused by the presence of permeable barriers (Borsje et al. 2019). Besides, MF1 also has a similarity in soil bulk density with AP4. Hence, these sites were not dissimilar concerning soil porosity, soil permeability, and soil ventilation (Avnimelech et al. 2001). In other words, four-year-old permeable barriers in AP4 resulted in a similar water-holding capacity with the effect of one-year-old permeable barriers and mangrove roots in MF1. Therefore, sediments accumulated and gradually expanded land territory in AP4 were expected to be appropriate for mangroves' colonization and growth when the barrier's strength reduces over time. A previous study reported that increasing the stand density and thickness of mangrove stands contributed to maintaining natural coastal stability (Yulianda et al. 2014).

A strong mud layer capable of maintaining the slope would provide an appropriate habitat for mangrove seedlings to grow at sediment. A previous study reported that Avicennia marina, a mangrove pioneer species that grows well in mudflats, colonized naturally behind permeable structures in Vietnam (Van Cuong et al. 2015; Nguyen et al. 2016). Hence, the presence of permeable barriers in abandoned ponds could potentially provide habitat for Avicennia sp. seedlings, which were also abundantly found in Sayung Sub-district. Avicennia species possess remarkable adaptations to high salinity (Table 4). Accordingly, Avicennia sp. constituted a greater portion of mangrove forests than Rhizophora sp. in this case study. Morphologically, Avicennia sp. is a salt-tolerant species. Avicennia sp. has a saline gland that supports its ability to adapt to high salinity environments and spreads throughout the intertidal zone (low, medium, and high intertidal positions) (Parida and Jha 2010; Woodroffe 2018). Also, the annual average air temperature tolerance in Avicennia sp. $\left(12.6{ }^{\circ} \mathrm{C}\right)$ was found to be higher than in Rhizophora sp. $\left(8.3^{\circ} \mathrm{C}\right)$; the mean sea surface temperature in Avicennia sp. $\left(11.1{ }^{\circ} \mathrm{C}\right)$ was also higher than in Rhizophora sp. $\left(7.2{ }^{\circ} \mathrm{C}\right)$ (Quisthoudt et al. 2012). Hence, the wide temperature range in Avicennia sp. indicates that this species is more tolerant of temperature changes. The use of A. marina for coastal restoration in similar ecological conditions is advisable, as this result suggests that $A$. marina is the most resilient species in both disturbed and harsh environments.

\section{Potential role of permeable barriers for abandoned ponds}

A variety of soil management techniques in coastal areas have resulted in changes in soil properties that also affect soil C storage ability (Bhomia et al. 2016). Where conversion of mangrove forests into aquaculture ponds 
regularly changes the biophysical soil that plays a role in controlling soil $\mathrm{C}$, previous study has reported that conversion of mangroves into shrimp ponds caused a reduction in TECS from $1023 \pm 87 \mathrm{Mg} \mathrm{C} \mathrm{ha}^{-1}$ to $499 \pm 56$ $\mathrm{Mg} \mathrm{C} \mathrm{ha}{ }^{-1}$ in Mahakam Delta (Arifanti et al. 2019). Construction activity of aquaculture ponds causes the removal of $\mathrm{C}$ from vegetation (tree and root), litter, and particular soil layers (Cameron et al. 2019). Besides, an increase in soil C's oxidation can occur during dyke formation activities that use excavated soil from aquaculture ponds (Sidik et al. 2013).

Low value of TECS in AP4 $\left(610.82 \pm 29.31 \mathrm{Mg} \mathrm{C} \mathrm{ha}^{-1}\right)$ and PP0 $\left(735.57 \pm 20.61 \mathrm{Mg} \mathrm{C} \mathrm{ha}^{-1}\right)$ than mangrove sites revealed that these sites were not covered by vegetation, suggesting that there was no significant contribution of organic matter from above- or belowground biomass. However, many seedling establishments of Avicennia sp. and Rhizophora sp. were found on AP4, while only a few seedlings of Rhizophora sp. occupied in the PP0. Nonetheless, it was unknown whether they were naturally recruited or artificially planted. At the same time, the lower value of soil C in AP4 was due to aerobic decomposition of organic matter in soil which triggered $\mathrm{C}$ oxidation during the draining period after harvesting (Towatana et al. 2002), while higher soil $\mathrm{C}$ in PP0 was caused by the concentration of organic $\mathrm{C}$ in the sediment originated from feed residue that accumulated in sediments at the bottom of the pond. A previous study revealed that organic matter from shrimp feed accounted for 80.33-92.48 \% total OC, 94.43-95.03\% total N, and 91.92-95.36\% total P, respectively (Sahu et al. 2012). Besides, since the N concentration in AP4 and PP0 was higher than other sampling sites, it resulted in the lower $\mathrm{C}: \mathrm{N}$ ratios in both areas, which indicated high carbonate content and well humification in soil (Simson et al. 2005).

This study also discovered that naturally regenerating mangroves in abandoned ponds protected by permeable barriers in Sayung Sub-district can enrich soil C, as seen in MF1 (704.13 $\left.\pm 17.73 \mathrm{Mg} \mathrm{C} \mathrm{ha}^{-1}\right)$ and MF4 (759.88 \pm 15.26 $\mathrm{Mg} \mathrm{C} \mathrm{ha}{ }^{-1}$ ). Moreover, comparing the protection of fouryear-old permeable barriers in covered and uncovered areas implied that mangroves contained an immense amount of C. Hence, the mean of TECS in MF4 $(826.14 \pm 24.41 \mathrm{Mg}$ $\left.\mathrm{C} \mathrm{ha}^{-1}\right)$ was higher than AP4 $\left(610.82 \pm 29.31 \mathrm{Mg} \mathrm{C} \mathrm{ha}^{-1}\right)$.

In conclusion, this study notes that (i) forest structures are not varied toward whether or not mangroves are protected by structural barriers, which cause the similarity in above- and below ground $\mathrm{C}$ due to the similarity of the basal area; (ii) the age of these barriers has a linkage to the variation of soil $\mathrm{C}$ due to the changes of soil bulk density, $\mathrm{N}$ concentration, and $\mathrm{C}: \mathrm{N}$ ratio, with findings show that the older the structures, the more $\mathrm{C}$-containing sediment could stored behind the structures until the age of four. In this case study, we suggests that naturally re-vegetating mangroves in abandoned ponds could be achieved in conjunction with constructing permeable barriers, particularly in coastal areas with severe erosion. We also highlight that the role of permeable barriers not only could enrich the TECS in mangrove forests but also potentially provide newly reclaimed coastline in abandoned ponds for the habitat of Avicennia sp. seedlings and therefore could assist in suppressing the release of $\mathrm{C}$ into the atmosphere.

\section{ACKNOWLEDGEMENTS}

The first author gratefully thanks the Ministry of Research, Technology, and Higher Education of the Republic of Indonesia for providing the Pendidikan Magister Menuju Doktor untuk Sarjana Unggul (PMDSU) Scholarship. We also acknowledge the grant provided by the United States Agency for International Development (USAID) to the Center for International Forestry Research (CIFOR) to operate the Sustainable Wetlands Adaptation and Mitigation Program (SWAMP), by which this research was organized.

\section{REFERENCES}

Arifanti VB, Kauffman JB, Hadriyanto D, Murdiyarso D, Diana R. 2019. Carbon dynamics and land-use carbon footprints in mangroveconverted aquaculture: The case of the Mahakam Delta, Indonesia. For Ecol Manag 432: 17-29.

Avnimelech Y, Ritvo G, Meijer LE, Kochba M. 2001. Water content, organic carbon and dry bulk density in flooded sediments. Aquacult Eng 25 (1): 25-33.

Bhomia RK, MacKenzie RA, Murdiyarso D, Sasmito SD, Purbopuspito J. 2016. Impacts of land use on Indian mangrove forest carbon stocks: Implications for conservation and management. Ecol Appl 26 (5): 1396-1408.

Borsje RM. 2019. Wave-Driven Set-Up of Fluid Mud: Demak, Indonesia. [Thesis]. Delft University of Technology, Delft.

Bouillon S, Dahdouh-Guebas F, Rao AVVS, Koedam N, Dehairs F. 2003. Sources of organic carbon in mangrove sediments: variability and possible ecological implications. Hydrobiologia 495 (1/3): 33-39.

Bray JR, Curtis JT. 1957. An ordination of the upland forest communities of southern Wisconsin. Ecol Monogr 27 (4): 325-349.

Cameron C, Hutley LB, Friess DA, Munksgaard NC. 2019. Hydroperiod, soil moisture and bioturbation are critical drivers of greenhouse gas fuxes and vary as a function of land-use change in mangroves of Sulawesi, Indonesia. Sci Total Environ 654: 365-377.

Cintrón G, Schaffer-Novelli Y. 1984. Methods for studying mangrove structure. In: Snedaker SC, Snedaker JG (eds) The Mangrove Ecosystems: Research Methods. UNESCO Monographs on Oceanographic Methodology, UNESCO, Paris.

Clarke KR, Gorley RN. 2006. PRIMER v6: user manual/tutorial. PRIMER-E, Plymouth, UK.

Climate-data.org. 2019. Demak climate (Indonesia). id.climatedata.org/location/26741/

Donato DC, Kauffman JB, Murdiyarso D, Kurnianto S, Stidham M, Kanninen M. 2011. Mangroves among the most carbon-rich forests in the tropics. Nat Geosci 4: 293-297.

Ervita K, Marfai MA. 2017. Shoreline change analysis in Demak, Indonesia. J Environ Prot 8: 940-955.

Gilman E, Ellison J, Jungblat V, Van Lavieren H, Wilson L, Areki F, Brighouse G, Bungitak J, Dus E, Henry M, Sauni Jr I, Kilman M, Matthews E, Teariki-Ruatu N, Tukia S, Yuknavage K. 2006. Adapting to Pacific Island mangrove responses to sea level rise and other climate change effects. Climate Res 32: 161-176.

Giri C, Ochieng E, Tieszen LL, Zhu Z, Singh A, Loveland T, Masek J, Duke N. 2010. Status and distribution of mangrove forests of the world using earth observation satellite data. Glob Ecol Biogeogr 20 (1): 154-159.

Hussain NA, Ali AH, Lazem LF. 2012. Ecological indices of key biological groups in Southern Iraqi marshland during 2005-2007. Mesopot J Mar Sci 27 (2): 112-125.

Ilman M, Dargusch P, Dart P, Onrizal. 2016. A historical analysis of the drivers of loss and degradation of Indonesia's mangroves. Land Use Policy 54: 448-459. 
Jørgensen SE, Xu F-L, Salas F, Marques JC. 2005. Application of indicators for the assessment of ecosystem health. In: Jørgensen SE, Costanza R, Xu FL (eds) Handbook of Ecological Indicators for Assessment of Ecosystem Health. CRC Press, Florida.

Kauffman JB, Adame MF, Arifanti VB, Schile-Beers LM, Bernardino AF, Bhomia RK, Donato DC, Feller IC, Ferreira TO, Garcia MCJ, MacKenzie RA, Megonigal JP, Murdiyarso D, Simpson L, and Trejo HH. 2020. Total ecosystem carbon stocks of mangroves across broad global environmental and physical gradients. Ecol Monogr 90 (2): e01405.

Kauffman JB, Donato D. 2012. Protocols for the measurement, monitoring and reporting of structure, biomass and carbon stocks in mangrove forests. Center for International Forestry Research (CIFOR), Bogor.

Komiyama A, Poungparn S, Kato S. 2005. Common allometric equations for estimating the tree weight of mangroves. J Trop Ecol 21: 471-477.

Lovelock CE, Feller IC, Mckee KL, Engelbrecht BMJ, Ball MC. 2004 The effect of nutrient enrichment on growth, photosynthesis and hydraulic conductance of dwarf mangroves in Panama. Funct Ecol 18: 25-33.

Marfai M. 2011. Impact of coastal inundation on ecology and agricultural land use case study in central Java, Indonesia. Quaest Geogr 30 (3): 19-32.

Margalef R. 1957. Information theory in ecology. Intl J Gen Syst 3: 36-71.

Morris R, Strain EMA, Konlechner TM, Fest BJ, Kennedy DM, Arnd SK, Swearer SE. 2019. Developing a nature-based coastal defense strategy for Australia. Aust J Civ Eng 17: 167-176.

Muller-Dubois, Ellenberg H. 1974. Aims and Method of Vegetation Ecology. John Wiley \& Sons, New York.

Murdiyarso D, Purbopuspito J, Kauffman JB, Warren MW, Sasmito SD, Donato D, Manuri S, Krisnawati H, Taberima S, Kurnianto S. 2015. The potential of Indonesian mangrove forests for global climate change mitigation. Nat Clim Change 5 (12): 1089-1092.

Muskananfola MR, Supriharyono, Febrianto S. 2020. Spatio-temporal analysis of shoreline change along the coast of Sayung Demak, Indonesia using Digital Shoreline Analysis System. Reg Stud Mar Sci 34:101060. DOI: 10.1016/j.rsma.2020.101060

Nam VN, Sasmito SD, Murdiyarso D, Purbopuspito J, MacKenzie RA. 2016. Carbon stocks in artificially and naturally regenerated mangrove ecosystems in the Mekong Delta. Wetl Ecol Manag 24 (2) 231-244.

Nguyen TP, Van Tam N, Quoi LP, Parnell KE. 2016. Community perspectives on an internationally funded mangrove restoration project: Kien Giang province, Vietnam. Ocean Coast Manag 119: 146-154.

Ong JE, Gong WK, Wong CH. 2004. Allometry and partitioning of the mangrove, Rhizophora apiculata. For Ecol Manag 188: 395-408.

Parida AK, Jha B. 2010. Salt tolerance mechanisms in mangroves: a review. Trees 24 (2): 199-217.

Pearson T, Walker S, Brown S. 2005. Sourcebook for land use, land-use change and forestry projects. In: Report from BioCF and Winrock International World Bank. Washington DC.

Pham VH, Luu VD, Nguyen TT, Koji O. 2017. Will restored mangrove forests enhance sediment organic carbon and ecosystem carbon storage? Reg Stud Mar Sci14: 43-52

Pielou EC. 1966. The measurements of diversity in different types of biological collections. J Theor Biol 13: 131-144.

Quisthoudt K, Schmitz N, Randin CF, Dahdouh-Guebas F, Robert EMR, Koedam N. 2012. Temperature variation among mangrove latitudinal range limits worldwide. Trees 26 (6): 1919-1931.
Sabiene N, Kusliene G, Zaleckas E. 2010. The influence of land use on soil organic \& nitrogen content redox potential. Agric 97 (3): 15-24.

Saengsupavanich C. 2013. Erosion protection options of a muddy coastline in Thailand: stakeholders' shared responsibilities. Ocean Coast Manag 83: 81-90.

Sahu BC, Adhikari S, Dey L. 2012. Carbon, nitrogen and phosphorus budget in shrimp (Penaeus monodon) culture ponds in eastern India. Aquac Intl 21 (2): 453-466.

Sahu SK, Kathiresan K. 2019. The age and species composition of mangrove forest directly influence the net primary productivity and carbon sequestration potential. Biocatal Agric Biotechnol 20: 101235. 10.1016/j.bcab.2019.101235.

Sasmito SD, Kuzyakov Y, Lubis AA, Murdiyarso D, Hutley LB, Bachri S, Friess DA, Martius C, Borchard N. 2020. Organic carbon burial and sources in soils of coastal mudflat and mangrove ecosystems. Catena 187: 104414. DOI: 10.1016/j.catena.2019.104414

Schmitt K, Albers T, Pham T, Dinh S. 2013. Site-specific and integrated adaptation to climate change in the coastal mangrove zone of Soc Trang province, Viet Nam. Coast Conserv 17 (3): 545-558.

Shannon CE. 1963. A mathematical theory of communication. Bell Syst Tech J 27: 379-423.

Sidik F, Lovelock CE. 2013. $\mathrm{CO}_{2}$ efux from shrimp ponds in Indonesia. PLoS One (8): e66329. DOI: 10.1371/journal.pone.66329

Simson T. 2005. Aliphatic compounds, organic C \& N \& microbial biomass \& its activity in long-term field experiment. Plant Soil Environ 51 (6): 276-282.

Smith-III TJ. 1992. Forest Structure. In: Robertson AI, Alongi DM (eds) Tropical Mangrove Ecosystems. American Geophysical Union, Washington DC.

Smits BP. 2019. Morphodynamic optimisation study of the design of semi-permeable dams for rehabilitation of a mangrove-mud coast: A case study of the Building-with-Nature project in Demak, Indonesia. [Thesis]. Delft University of Technology, Delft.

Subardjo P. 2004. Morphological study for mapping tidal inundation in Sayung coast Demak Central Java. Mar Sci 9 (3): 153-159. [Indonesian].

Thoai DT, Dang AN, Oanh NTK. 2019. Analysis of coastline change in relation to meteorological conditions and human activities in $\mathrm{Ca}$ mau cape, Viet Nam. Ocean Coast Manag 171: 56-65.

Towatana P, Voradaj C, Panapitukkul N. 2002. Changes in soil properties of abandoned shrimp ponds in southern Thailand. Environ Monit Assess 74 (1): 45-65.

Tyson RV. 1995. Sedimentary Organic Matter: Organic Facies and Palynofacies. Chapman and Hall, London.

Van Cuong C, Brown S, To H, Hockings M. 2015. Using melaleuca fences as soft coastal engineering for mangrove restoration in Kien Giang (Vietnam). Ecol Eng 81: 256-265.

van Wagner CE. 1968. The line-intersect method in forest fuel sampling. For Sci 14: 20-26.

Winterwerp H, Van Wesenbeeck B, Van Dalfsen J, Tonneijck F, Astra A, Verschure S, Van Eijk P. 2014. A sustainable solution for massive coastal erosion in Central Java. Deltares and Wetlands International, Nederland.

Woodroffe CD. 2018. Mangrove response to sea level rise: palaeoecological insights from macrotidal systems in northern Australia. Mar Freshw Res 69 (6): 917-932.

Yulianda F, Wardiatno Y, Nurjaya IW, Herison A. 2014. Coastal conservation strategy using mangrove ecology system approach. Asian J Scient Res 7: 513-524. 